\section{Can Perfusion Index or Pleth Variability Index Predict Spinal Anesthesia-Induced Hypotension During Caesarean Section?}

\author{
Sezaryen Operasyonlarında Spinal Anesteziye \\ Bağlı Hipotansiyon Perfüzyon Indeksi veya Pleth \\ Variabilite Indeks ile Öngörülebilir mi?
}

Mahmut Arslan (D) Gözen Öksüz ๑ Bora Bilal $₫$

Cengizhan Yavuz (1)

Mehmet Kandilcik (1) Adem Doğaner (1) Feyza Çalışır (1)

\begin{abstract}
Objective: Although spinal anesthesia is the preferred anesthetic method for cesarean sections, it leads to hypotension in a significant proportion of the patients. In this study, we assessed the predictive ability of perfusion index (PI) and Pleth variability index (PVI) in different positions, for prediction of hypotension after spinal anesthesia administered for cesarean delivery.

Methods: Ninety parturients scheduled for elective lower segment cesarean section under spinal anesthesia were enrolled in the study. In the preoperative holding area, PI and PVI values were recorded in the supine, semi-recumbent, passive leg raise and left lateral positions. Then, parturients were taken to the operating room; their PI and PVI values were recorded again in the supine and sitting positions. Spinal anesthesia was performed with $0.5 \%$ hyperbaric bupivacaine $(10 \mathrm{mg})$ injected through L3-L4 or L4-L5 interspaces with the patient in the sitting position. PI and PVI values were recorded one minute after induction of spinal anesthesia as postspinal measurements. The effects of independent variables on hypotension were examined with logistic regression analysis. The relationship between PI and PVI values and incidence of hypotension was evaluated using ROC analysis.

Results: The incidence of hypotension was 60 percent. Postspinal PVI was found to have a weak predictive value for postspinal hypotension ( $A \cup C=0.663,95 \% \mathrm{Cl} 0.530-0.796, p=0.024$ ).

Conclusion: Among the parameters evaluated, only postspinal PVI was associated with spinal anesthesia-induced hypotension in cesarean section. However, it may not be useful in routine clinical practice due to its low specificity and sensitivity.
\end{abstract}

Keywords: Perfusion index, Pleth variability index, spinal anesthesia, hypotension, cesarean section

öz

Amaç: Sezaryen operasyonlarında tercih edilen anestezi yöntemi spinal anestezidir, ancak hastaların önemli bir kısmında hipotansiyona yol açar. Bu çalışmada, farklı pozisyonlardaki perfüzyon indeksi (Pi) ve pleth variabilite indeksi (PVi) değerlerinin sezaryen operasyonu için uygulanan spinal anestezi sonrası gelișen hipotansiyonu öngörme kabiliyetini değerlendirdik.

Yöntem: Spinal anestezi ile alt segment sezaryen operasyonu olacak 90 gebe çalışmaya dahil edildi. Preoperatif hazırlık odasında supin, yarı oturur, pasif bacak kaldırma ve sol lateral dekübit pozisyonlarda iken, PI ve PVi değerleri kaydedildi. Sonra hastalar ameliyat odasına alındı ve supin ve oturur pozisyonlarda PI ve PVI değerleri yeniden kaydedildi. Oturur pozisyonda L3-L4 veya L4-L5 aralıklarından $10 \mathrm{mg} \% 0.5$ bupivakain ile spinal anestezi uygulandı. Spinal anesteziden bir dk sonraki Pi ve PVi değerleri postspinal değerleri olarak kaydedildi. Bağımsız değişkenlerin hipotansiyon üzerine etkileri logistik regresyon analizi ile değerlendirildi. Pi ve PVi değerleri ile hipotansiyon arasındaki ilişki ROC analizi ile değerlendirildi.

Bulgular: Hipotansiyon insidansı \%60 idi. Spinal sonrası hipotansiyon için post-spinal PVi değerinin zayıf prediktif değeri olduğunu saptadık ( $A U C=0.663,95 \% \mathrm{Cl} 0.530-0.796, p=0.024$ ).

Sonuç: Değerlendirilen parametreler arasında, sezaryen operasyonlarında spinal anesteziye bağlı gelişen hipotansiyonla yalnızca post-spinal PVi arasında ilişki saptandı. Ancak, bu değerin düşük spesifisite ve sensitivitesi nedeniyle rutin klinik uygulamada yararlı olmayabilir.

Anahtar kelimeler: Perfüzyon indeksi, pleth variabilite indeks, spinal anestezi, sezaryen operasyonu
Alındığı tarih: 02.08.2019

Kabul tarihi: 01.10.2019

Yayın tarihi: 31.10 .2019

Atıf vermek için: Arslan M, Öksüz G, Bilal B, Yavuz C, Kandilcik M, Doğaner A, Çalışır F. Can perfusion index or pleth variability index predict spinal anesthesia induced hypotension during caesarean section?. JARSS 2019;27(4):251-7.

\section{Mahmut Arslan \\ Kahramanmaraş Sütçü İmam \\ Üniversitesi, Tıp Fakültesi, Anesteziyoloji ve Reanimasyon \\ Anabilim Dalı, \\ Kahramanmaraş, Türkiye mahmutarslan177@gmail.com ORCID: 0000-0002-2820-1547}

G. Öksüz 0000-0001-5197-8031 B. Bilal 0000-0003-3884-8042 C. Yavuz 0000-0003-4627-7403 M. Kandilcik 0000-0002-8916-5156 Kahramanmaraş Sütçü Imam Üniversitesi, Tıp Fakültesi, Anesteziyoloji ve Reanimasyon Anabilim Dalı,

Kahramanmaraş, Türkiye

A. Doğaner 0000-0002-0270-9350 Kahramanmaraş Sütçü Imam Üniversitesi, Tıp Fakültesi, Biyoistatistik ve Tıbbi Bilişim Anabilim Dalı, Kahramanmaraş, Türkiye

F. Çalışır 0000-0002-8882-4666 Necip Fazıl Şehir Hastanesi, Anesteziyoloji ve Reanimasyon Bölümü,

Kahramanmaraş, Türkiye 


\section{INTRODUCTION}

Spinal anesthesia (SA) is the most preferred anesthetic method in cesarean deliveries because it eliminates the potential risks associated with airway management in pregnant women ${ }^{(1)}$. However, SA leads to hypotension in approximately $70 \%$ of patients, which may vary based on the definition of hypotension used ${ }^{(2)}$. Aortocaval compression caused by the uterus and a decrease in systemic vascular resistance due to sympathetic block induced by SA are important factors in the formation of hypotension (1). Hypotension may cause dizziness, nausea, and vomiting in the mother, and acidosis in the fetus.

To prevent hypotension, many approaches have been recommended, such as fluid preloading, vasopressor agent administration, left uterine displacement, and using compression stockings ${ }^{(3)}$. Since the effects of strategies aiming to increase intravascular volume are limited, the use of vasopressor agents has become more popular in recent years ${ }^{(1)}$. However, administration of prophylactic vasopressor agents in pregnant women may cause undesirable effects on the mother and fetus. Therefore, studies have been carried out with noninvasive methods, such as thoracic electrical bioimpedance, measurement of heart rate variability, cerebral near-infrared spectroscopy, point-of-care ultrasound, perfusion index (PI), and Pleth variability index (PVI) to predict which parturient would develop hypotension ${ }^{(4-14)}$.

$\mathrm{PI}$ is obtained by calculating the ratio of pulsatile blood flow in peripheral tissues to nonpulsatile blood flow by pulse oximetry ${ }^{(15)}$. This ratio reflects changes in peripheral vascular resistance. For example, a low PI indicates peripheral vasoconstriction. The $\mathrm{PVI}$ represents changes in $\mathrm{PI}$, which occur during one or more complete respiratory cycles. It allows for evaluation of intravascular volume; and a higher PVI is associated with greater responsiveness to fluid volumes ${ }^{(16)}$

Studies have shown that $\mathrm{PI}$ and $\mathrm{PVI}$ values obtained from pulse oximetry are predictors for SA-induced hypotension in cesarean deliveries (7,8,10,11); however, evidence to the contrary has also been presented $(9,12)$. Thus, we aimed to test the hypothesis that hypotension after SA could be predicted in pregnant women by using PVI which represents cardiac preload and PI which represents vascular tone. Additionally, we considered postural changes while testing our hypothesis.

\section{MATERIAL and METHODS}

This study was approved by the Local Ethics Committee (2018-163) and registered on the ClinicalTrials.gov Protocol Registration and Results System (NCT03864692). Ninety singleton parturients scheduled for elective lower segment cesarean section under SA were included in this prospective observational study. Written informed consent was obtained from all patients. The exclusion criteria were as follows: emergency cases, age $<18$ or $>40$ years, gestational age $<36$ weeks, $\mathrm{BMI} \geq 40$, refusal to participate, and presence of placenta previa, preeclampsia, cardiovascular disease, Raynaud's disease, fetal complications, or contraindications to SA.

All parturients fasted for at least 8 hours for solid food and 3 hours for clear liquids. After parturients were taken to the preoperative holding area (room temperature, $24^{\circ} \mathrm{C}$ ) a Masimo Radical 7 probe (Masimo Corp., Irvine, CA, USA) was placed on the right ring finger to measure $\mathrm{PI}$ and $\mathrm{PVI}$ values. Venous cannulation procedures with an 18-G cannula was applied to the left hand. After the patients had rested in the supine position for 5 minutes, systolic blood pressure (SBP), mean blood pressure $(\mathrm{MBP})$, heart rate $(\mathrm{HR})$, and $\mathrm{PI}$ and $\mathrm{PVI}$ values were recorded. The same measurements were repeated with the patient in a $45^{\circ}$ semi-recumbent position, $45^{\circ}$ passive leg raise position, and finally the left lateral position. Following each position change, we waited 5 min before recording measurements. After measurement recording was completed, the patient was taken to the operating room. PI and PVI values were recorded again with the patient in the supine position, and again in the sitting position for SA. SA was performed with $0.5 \%$ hyperbaric bupivacaine (10 mg) injected through L3-L4 or L4-L5 interspaces in all patients in the sitting position. After induction of $S A$, the parturient was returned to the supine position with a left lateral tilt of $10-15^{\circ}$, and loading dose of intravenous crystalloid (15 mL kg) together with rapid infusion of $0.9 \%$ saline was started. Then, $4 \mathrm{~L} / \mathrm{min} \mathrm{O}_{2}$ was delivered through a face mask. Heart 
rate and blood pressure were recorded at 1-minute intervals until delivery, and at 5-minute intervals after delivery. $\mathrm{PI}$ and $\mathrm{PVI}$ values measured at the $1^{\text {st }}$ minute after SA were recorded as the "postspinal $\mathrm{PVI}$ " and "postspinal $\mathrm{Pl}$ ", respectively SBP $<80 \mathrm{mmHg}$ or presence of symptoms consistent with hypotension (such as dizziness, nausea, and vomiting) even without $\mathrm{SBP}<80 \mathrm{mmHg}$ was defined as postspinal hypotension. These patients were classified as the hypotension group and the others as the nonhypotension group. Postspinal hypotension was treated with intravenous boluses of $8 \mu \mathrm{g}$ norepinephrine. Intravenous atropine $0.5 \mathrm{mg}$ was applied in those with pulse rates of $<55 \mathrm{bpm}$. The sensory block level was assessed 5 and 10 minutes after spinal injection by pinprick test. If a T6 sensory block level was not achieved up to 10 minutes after SA, the parturient was excluded from the study. Apgar scores at 1 and 5 min after delivery were recorded.

A preliminary study was conducted to determine the number of samples necessary for inclusion in the study. In the preliminary study, 7 of 15 patients developed hypotension. In patients with and without hypotension, supine PVI values were $24.4 \pm 7.45$; and $18.2 \pm 8.06$, respectively. Based on this information, it was deemed it appropriate to include 74 patients in the study to establish $\alpha: 0.05$ Type I error level, $\beta: 0.10$ Type II error level, and statistical power of 0.90. Finally, 90 patients were included in the study to increase the strength and reliability of the findings. $R$ 3.3.2 software was used to determine the sample size.

\section{Statistical Analysis}

Kolmogorov-Smirnov test was used to analyze normality of the distribution of variables. In variables with normal distribution, group comparisons were performed with independent samples t-test. Quantitative data were expressed as mean and standard deviation (SD). Group comparisons were performed using the Mann-Whitney $U$ test in variables without normal distribution. The descriptive statistics were expressed as median (1st quartile-3rd quartile). The effect of independent variables on hypotension was analyzed with binary logistic regression analysis. Frequency distributions of categorical variables were analyzed with (Pearson chi-square test etc) chi-square test and Fisher's exact test. Receiver operating characteristic (ROC) curves were used to determine the cut-off value of postspinal PVI. Statistical significance was accepted at $p<0.05$. Data were evaluated by IBM SPSS version 22.0 software (IBM SPSS version 22.0, IBM Corporation, Armonk, New York, United States).

\section{RESULTS}

Three parturients were excluded from the analysis because their sensory block level did not reach T6. Of 87 patients included in the analysis, 53 (60\%) developed hypotension after SA. Patient and obstetric characteristics are shown in Table I. There was no difference in gestational weeks, sensory block levels, age, and BMI between patients with (hypotension

Table I. Patient and obstetric characteristics

\begin{tabular}{lccc}
\hline & $\begin{array}{c}\text { Hypotension } \\
(\mathbf{n}=53)\end{array}$ & $\begin{array}{c}\text { Non-hypotension } \\
(\mathbf{n}=\mathbf{3 4})\end{array}$ & $\mathbf{p}$ \\
\hline Age (years) & $29.3(5.9)$ & $30.2(5.2)$ & 0.484 \\
Height (cm) & $162(6.3)$ & $163.3(6.9)$ & 0.363 \\
Weight (kg) & $78.4(10.3)$ & $78.9(14.2)$ & 0.857 \\
BMI (kg m ${ }^{2-1}$ ) & $29.9(3.3)$ & $29.5(4.9)$ & 0.724 \\
Gestational age (weeks) & $38.3[38.0-38.6]$ & $38.4[38.0-38.6]$ & 0.847 \\
Time of surgery (min) & $43[37-50]$ & $40[35-50]$ & 0.551 \\
Apgar score & & & \\
1 min & $9[8-9]$ & $9[8-9]$ & 0.713 \\
5 min & $10[9-10]$ & $10[9-10]$ & 0.199 \\
& & &
\end{tabular}

Parameters are expressed as mean (SD), median [Q1-Q3]. BMI: Body mass index

Table II. PI and PVI values

\begin{tabular}{|c|c|c|c|}
\hline & $\begin{array}{l}\text { Hypotension } \\
\quad(n=53)\end{array}$ & $\begin{array}{c}\text { Non-hypotension } \\
(n=34)\end{array}$ & $\mathbf{P}$ \\
\hline $\begin{array}{l}\text { Sensory block level } \\
\text { PVI }\end{array}$ & T4 [T4-T5] & T4 [T4-T6] & 0.43 \\
\hline $\begin{array}{l}\text { Preoperative supine } \\
\text { position }\end{array}$ & $20.2(7.2)$ & $17.3(4.4)$ & $0.036^{*}$ \\
\hline Semi-recumbent position & $20.1(7.3)$ & $18(4.9)$ & 0.154 \\
\hline Passive leg raise position & $20.2(6.5)$ & $19.6(5.6)$ & 0.637 \\
\hline Left lateral position & $20.3(6.9)$ & $20.2(6.1)$ & 0.911 \\
\hline Supine position in the OR & $20.6(8.3)$ & $20.1(7.5)$ & 0.768 \\
\hline Sitting position & $21.8(6.4)$ & $21.2(8.6)$ & 0.716 \\
\hline $\begin{array}{l}\text { Post-spinal } \\
\mathrm{PI}\end{array}$ & $20.8(5.8)$ & $18.6(6.9)$ & 0.135 \\
\hline $\begin{array}{l}\text { Preoperative supine } \\
\text { position }\end{array}$ & $6.4[4.1-8.9]$ & $6.5[4.6-9.2]$ & 0.629 \\
\hline Semi-recumbent position & $6.0[4.1-8.2]$ & $6.0[4.2-8.4]$ & 0.841 \\
\hline Passive leg raise position & 5.7 [4.4-9.3] & $6.8[4.8-9.7]$ & 0.408 \\
\hline Left lateral position & $5.8[4.1-7.6]$ & $5.8[3.6-7.8]$ & 0.818 \\
\hline Supine position in the OR & $2.35[1.5-3.4]$ & $2.60[1.7-4.2]$ & 0.346 \\
\hline Sitting position & $1.90[1.2-2.9]$ & $2.00[1.3-3.3]$ & 0.543 \\
\hline Post-spinal & $2.60[1.8-3.9]$ & $2.80[1.6-5.1]$ & 0.720 \\
\hline
\end{tabular}

OR: Operating room; PVI: Pleth variability index; PI: Perfusion index. Parameters are expressed as mean (SD), median [Q1-Q3]. *Statistically significant 
group) and without hypotension (non-hypotension group). Table II shows PI and PVI values of the patients. Preoperative supine-position PVI values were higher in the hypotension group than in nonhypotension group $(p=0.036)$. No difference was observed as for other positions and recording times. In terms of PI values, there was no difference between two groups at any position or time.

ROC analysis was used to assess the ability of $\mathrm{PI}$ and PVI to predict hypotension. Only postspinal PVI was found to have a predictive value for postspinal hypotension ( $A \cup C=0.663$; 95\% Cl 0.530-0.796, $\mathrm{p}=0.024$; Figure 1 and Table III). The optimal cut-off point of postspinal PVI to predict the occurrence of postspinal hypotension was 18.5 with a sensitivity of $63 \%$ and specificity of $58.5 \%$. No other PI and PVI measurements had predictive value. Multivariate logistic regression analysis showed that postspinal PVI was an independent risk factor for SA-induced hypotensi-

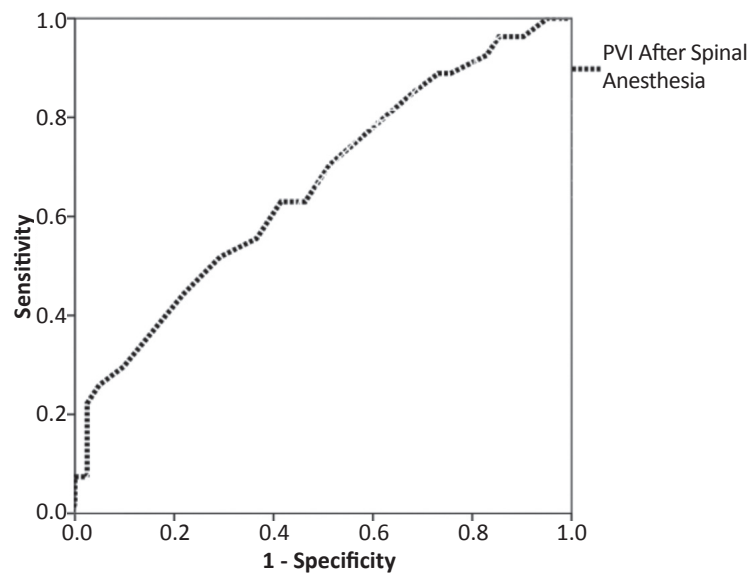

Figure 1. Receiver operating characteristic curve for post-spinal PVI to predict post-spinal hypotension. PVI: Pleth variability index. AUC:0.663; p:0.024; cut-off:18.50; sensivity: 0.630; specificity: $\mathbf{0 . 5 8 5}$

Table III. Receiver operating characteristic analysis for PVI to predict post-spinal hypotension

\begin{tabular}{lccc}
\hline & AUC & $\mathbf{p}$ & $\% 95 \mathrm{Cl}$ \\
\hline Post-spinal PVI & 0.663 & $0.024 *$ & $0.530-0.796$ \\
Preoperative supine position PVI & 0.586 & 0.234 & $0.452-0.720$ \\
Semi-recumbent position PVI & 0.561 & 0.394 & $0.424-0.699$ \\
Passive leg raise position PVI & 0.485 & 0.831 & $0.345-0.625$ \\
Lefte lateral positon PVI & 0.471 & 0.688 & $0.332-0.610$ \\
Supine position in the OR PVI & 0.511 & 0.880 & $0.371-0.651$ \\
Sitting position PVI & 0.556 & 0.441 & $0.414-0.697$
\end{tabular}

PVI: Pleth variability index; OR: Operating room; Cl: Confidence interval. *Statistically significant. For post-spinal PVI: cut-off:18.50; sensivity:0.630; specificity:0.585. on (odds ratio: $0.741,95 \% \mathrm{Cl}: 0.595-0.922, \mathrm{p}=0.007$ ) (Table IV).

Table IV. Individual variable Logistic Regression Analysis to predict the incidence of postspinal hypotension

\begin{tabular}{lcccc}
\hline & $\begin{array}{l}\text { Odds } \\
\text { Ratio }\end{array}$ & 95\% Cl & p \\
& & & \\
\hline Preoperative supine position PVI & 0.823 & 0.637 & 1.063 & 0.136 \\
Semi-recumbent position PVI & 0.914 & 0.713 & 1.171 & 0.476 \\
Passive leg raise position PVI & 0.992 & 0.777 & 1.267 & 0.952 \\
Left lateral position PVI & 1.228 & 0.950 & 1.587 & 0.118 \\
Supine position in the OR PVI & 1.159 & 0.975 & 1.378 & 0.095 \\
Sitting position PVI & 1.082 & 0.904 & 1.297 & 0.390 \\
Post-spinal PVI & 0.741 & 0.595 & 0.922 & $0.007^{*}$ \\
Age & 1.079 & 0.929 & 1.252 & 0.319 \\
Gestational age & 1.765 & 0.764 & 4.078 & 0.184 \\
BMI & 0.918 & 0.729 & 1.156 & 0.469 \\
\hline
\end{tabular}

Cl: Confidence interval; BMI: Body mass index. *Statistically significant.

\section{DISCUSSION}

In this study, we aimed to predict SA-induced hypotension in singleton parturients undergoing cesarean section using pre- and post-SA PI and PVI values. We repeated these measurements preoperatively, in supine, $45^{\circ}$ semi-recumbent, $45^{\circ}$ passive leg raise, and left lateral positions and then in the operating room immediately before $S A$, in the sitting position and immediately after SA. We hypothesized that PI and PVI values measured using pulse oximetry would vary with changes in uterine compression and venous return due to postural changes. We analyzed these 14 data points at different positions and found that only postspinal PVI could predict hypotension after SA for cesarean delivery. However, ROC analyses based on pulse oximetry values indicated that postspinal PVI was a weak predictor of SA-induced hypotension. No other PI and PVI measurements, including differences in $\mathrm{PI}$ and $\mathrm{PVI}$ due to postural changes had a predictive value. In the multivariate logistic regression analysis, postspinal PVI was shown to be an independent risk factor for hypotension after SA.

PVI has been shown to be a good predictor for fluid responsiveness in patients on mechanical ventilation ${ }^{(16-19)}$. Since the tidal volume and frequency are constant in patients with mechanical ventilation, PI change in the respiratory cycle is more constant. In patients with spontaneous breathing, PI changes are more dynamic as tidal volume and frequency change 
continuously. However, studies have shown that PVI reflects fluid responsiveness accurately in patients with spontaneous breathing ${ }^{(20)}$. One study indicated that $\mathrm{PVI}$ reflects the volume of central extracellular fluid (21). Because of its relationship with patient's fluid states, SA-induced hypotension may be expected to be seen more frequently in cesarean deliveries in parturients with higher PVI values.

Studies have investigated whether PVI values can be useful for predicting hypotension after SA in cesarean deliveries ${ }^{(7-9,12)}$. Kuwata et al. ${ }^{(7)}$ measured $\mathrm{PI}$ and $\mathrm{PVI}$ in supine and lateral positions before anesthesia and in supine position after anesthesia, and reported that PVI before and after SA, and PI change were good predictors of SA-induced hypotension ( $A \cup C=0.751,0.793$, and 0.731 , respectively). In their study, PVI before SA was significantly higher in the hypotension group than the non-hypotension group. Similarly, in their study, Sun et al. ${ }^{(8)}$ found that baseline PVI was higher in the hypotension group than non-hypotension group. Multivariate analysis revealed that baseline PVI was associated with the incidence of hypotension, and, in ROC analysis, AUC for predicting hypotension by baseline PVI was 0.66 . The authors indicated that baseline PVI has a poor diagnostic accuracy and is therefore unlikely to be clinically useful. In our study, baseline supine PVI was higher in the hypotension group; however, in multivariate analysis, only postspinal PVI and not baseline supine PVI was associated with incidence rates of hypotension. In contrast to these studies, 2 studies showed no correlation between baseline PVI values and development of hypotension ${ }^{(9,12)}$. In a study evaluating the predictive abilities of noninvasive hemodynamic parameters ( $\mathrm{PI}, \mathrm{PVI}$, heart rate, heart rate variability), Yokose et al. ${ }^{(9)}$ showed that only heart rate has a predictive value while PVI has not. Again, Wrench et al. ${ }^{(12)}$ reported lack of any correlation between PVI values and hypotension. There may be many reasons for the contradictions between the results of these studies. While the definition of hypotension was the same as ours in the study by Yokose et al. ${ }^{\left({ }^{9}\right)}$, the percentage of decline in SBP was used in the others ${ }^{(7,8,12)}$. While the evaluation period for hypotension was 'until delivery' in some studies $(7,9)$ it was 20 minutes in one ${ }^{(12)}$, and the entire duration of surgery in another ${ }^{(8)}$. In one study, the fluid management method was determined by the anest- hesiologist, while different preloading and co-loading strategies were used in the others. These differences in study methodology can account for the variable results about predictive abilities of PI and PVI values for SA-induced hypotension. In this study, we defined postspinal hypotension as SBP $<80 \mathrm{mmHg}$ or presence of symptoms of hypotension. We established the duration of study to be until delivery because other factors such as blood loss after birth and oxytocin administration might affect the incidence of hypotension. We did not perform routine fluid preloading for parturients, and we applied standard fluid co-loading after SA.

$\mathrm{PI}$ and PVI values are affected by factors such as ambient temperature, and patients' stress and anxiety. Therefore, in our study, we performed preoperative measurements in a calm environment and at a room temperature of $24^{\circ} \mathrm{C}$ in the preoperative holding area. A decrease in PI values was observed in both groups possibly caused by increased stress levels when patients were brought into the operating room.

In our study, we did not determine predictive importance of PI values measured in different positions for postspinal hypotension in parturients. Studies have shown that PI value is not predictive for hypotension in agreement with the results of our study ${ }^{(7-9)}$. In one study, change in PI after SA was shown to be a good predictor, although PI was not. In contrast, Toyoma et al. ${ }^{(10)}$ showed that a preanesthetic $\mathrm{PI}$ of $>3.5$ predicted the incidence of hypotension in cesarean deliveries with a sensitivity and specificity of $81 \%$ and $86 \%$, respectively (AUC $=0.87$ ). Supporting the results of their research, Duggappa et al. ${ }^{(22)}$ stated that a baseline $\mathrm{PI}$ of $>3.5$ was associated with higher incidence of hypotension after SA in cesarean deliveries. These inconsistent results may be related to the different study designs mentioned above. $\mathrm{PI}$ is a noninvasive measure of peripheral perfusion and it is affected by changes in the sympathetic tone. Sympathetic block level is usually 2-6 segments higher than the sensory block level after SA (23). Postganglionic fibers providing major sympathetic innervation of the upper extremity originate from $\mathrm{T} 2$ nerve roots ${ }^{(24)}$. Although the T6 sensory block level is targeted during SA, the sympathetic block may reach the $\mathrm{T} 2$ level in some parturients. In this case, 
regardless of other factors, the PI may increase and $\mathrm{PVI}$ may change. Therefore, the results of $\mathrm{PI}$ and $\mathrm{PVI}$ measurements after SA will change based on the level of sympathetic block, thus making it difficult to predict the occurrence of hypotension by using these values exclusively.

There are some limitations in our study. Firstly, colder ambient temperatures, and patient stress, anxiety, and movement might have affected PI and PVI values. To minimize such effects, preoperative measurements were made in the calm and warm ambience of the preoperative holding area and parturients rested for 5 minutes before each measurement. Secondly, we did not perform continuous invasive arterial blood pressure monitoring because there was no medical indication to do so; instead, we measured blood pressures intermittently. Since direct aortocaval compression would directly affect the vessels of the lower extremity, future studies should focus on the predictive abilities of PI and PVI measured in the toe on SA-induced hypotension during cesarean section.

\section{CONCLUSION}

In this study, we investigated the predictive value of $\mathrm{PI}$ and $\mathrm{PVI}$ measured in different positions for SA-induced hypotension in cesarean section. We found that only postspinal PVI was predictive. However, because of its poor predictive value, sensitivity, and specificity, postspinal-PVI may not be useful in routine clinical practice.

Etik Kurul Onayı: Kahramanmaraş Sütçü İmam Üniversitesi Tıp Fakültesi Klinik Araştırmalar Etik Kurul onayı alınmıştır.

Çıkar Çatışması: Yoktur

Finansal Destek: Yoktur

Hasta Onamı: Hasta onamları alındı.

Ethics Committee Approval: Kahramanmaras Sütçü Imam University Faculty of Medicine Clinical Research Ethics Committee approval was obtained.

Conflict of Interest: None

Funding: None

Informed Consent: The patients' consent were obtained.

\section{REFERENCES}

1. Lee JE, George RB, Habib AS. Spinal-induced hypotension: incidence, mechanisms, prophylaxis, and management: Summarizing 20 years of research. Best Pract Res Clin Anaesthesiol. 2017;31:57-68. https://doi.org/10.1016/j.bpa.2017.01.001

2. Klohr S, Roth R, Hofmann T, Rossaint R, Heesen M. Definitions of hypotension after spinal anaesthesia for caesarean section: literature search and application to parturients. Acta Anaesthesiol Scand. 2010;54:909-21. https://doi.org/10.1111/j.1399-6576.2010.02239.x

3. Kinsella S, Carvalho B, Dyer R, et al. International consensus statement on the management of hypotension with vasopressors during caesarean section under spinal anaesthesia. Anaesthesia. 2018;73:71-92. https://doi.org/10.1111/anae.14080

4. Ouzounian JG, Masaki DI, Abboud TK, Greenspoon JS. Systemic vascular resistance index determined by thoracic electrical bioimpedance predicts the risk for maternal hypotension during regional anesthesia for cesarean delivery. Am J Obstet Gynecol. 1996;174:10191025. https://doi.org/10.1016/S0002-9378(96)70343-5

5. Hanss R, Bein B, Ledowski T, et al. Heart rate variability predicts severe hypotension after spinal anesthesia for elective cesarean delivery. Anesthesiology. 2005;102:1086-93. https://doi.org/10.1097/00000542-200506000-00005

6. Berlac PA, Rasmussen YH. Peroperative cerebral nearinfrared spectroscopy (NIRS) predicts maternal hypotension during elective caesarean delivery in spinal anaesthesia. Int J Obstet Anesth. 2005;14:26-31. https://doi.org/10.1016/j.ijoa.2004.06.003

7. Kuwata S, Suehiro K, Tsujimoto S, et al. Pleth variability index can predict spinal anaesthesia-induced hypotension in patients undergoing caesarean delivery. Acta Anaesthesiologica Scandinavica. 2018;62:75-84. https://doi.org/10.1111/aas.13012

8. Sun S, Huang SQ. Role of pleth variability index for predicting hypotension after spinal anesthesia for cesarean section. Int J Obstet Anesth. 2014;23:324-9. https://doi.org/10.1016/j.ijoa.2014.05.011

9. Yokose M, Mihara T, Sugawara Y, Goto T. The predictive ability of non-invasive haemodynamic parameters for hypotension during caesarean section: A prospective observational study. Anaesthesia. 2015;70:555-62. https://doi.org/10.1111/anae.12992

10. Toyama S, Kakumoto M, Morioka M, et al. Perfusion index derived from a pulse oximeter can predict the incidence of hypotension during spinal anaesthesia for caesarean delivery. Br J Anaesth. 2013;111:235-41. https://doi.org/10.1093/bja/aet058

11. Xu Z, Xu T, Zhao P, et al. Differential Roles of the Right and Left Toe Perfusion Index in Predicting the Incidence of Postspinal Hypotension During Cesarean Delivery. Anesth Analg. 2017;125:1560-6. https://doi.org/10.1213/ANE.0000000000002393

12. Wrench I, Hammon L, Handa S, Mahajan R. Changes in pleth variability index and detection of hypotension during spinal anaesthesia for caesarean section . Int J Obstet Anesth. 2015;24:388-9. https://doi.org/10.1016/j.ijoa.2015.07.001 
13. Zieleskiewicz L, Noel A, Duclos G, et al. Can point-ofcare ultrasound predict spinal hypotension during caesarean section? A prospective observational study. Anaesthesia. 2018;73:15-22. https://doi.org/10.1111/anae.14063

14. Sakata K, Yoshimura N, Tanabe K, et al. Prediction of hypotension during spinal anesthesia for elective cesarean section by altered heart rate variability induced by postural change. Int J Obstet Anesth. 2017;29:34-8. https://doi.org/10.1016/j.ijoa.2016.09.004

15. Goldman JM, Petterson MT, Kopotic RJ, Barker SJ. Masimo signal extraction pulse oximetry. J Clin Monit Comput. 2000;16:475-83. https://doi.org/10.1023/A:1011493521730

16. Cannesson $M$, Desebbe $O$, Rosamel $P$, et al. Pleth variability index to monitor the respiratory variations in the pulse oximeter plethysmographic waveform amplitude and predict fluid responsiveness in the operating theatre. Br J Anaesth. 2008;101:200-6. https://doi.org/10.1093/bja/aen133

17. Lee HC, Tsai YF, Tsai HI, et al. Pulse oximeter-derived pleth variability index is a reliable indicator of cardiac preload in patients undergoing liver transplantation. Transplant Proc. 2016;48:1055-8. https://doi.org/10.1016/j.transproceed.2015.12.106

18. Zimmermann M, Feibicke T, Keyl C, et al. Accuracy of stroke volume variation compared with pleth variability index to predict fluid responsiveness in mechanically ventilated patients undergoing major surgery. Eur J Anaesthesiol. 2010;27:555-61.
https://doi.org/10.1097/EJA.0b013e328335fbd1

19. Hood JA, Wilson RJ. Pleth variability index to predict fluid responsiveness in colorectal surgery. Anesth Analg. 2011;113:1058-63. https://doi.org/10.1213/ANE.0b013e31822c10cd

20. Keller G, Cassar E, Desebbe O, Lehot JJ, Cannesson M. Ability of pleth variability index to detect hemodynamic changes induced by passive leg raising in spontaneously breathing volunteers. Crit Care. 2008;12:R37. https://doi.org/10.1186/cc6822

21. Lu W, Dong J, Xu Z, et al. The pleth variability index as an indicator of the central extracellular fluid volume in mechanically ventilated patients after anesthesia induction: comparison with initial distribution volume of glucose. Med Sci Monit. 2014;20:386-92. https://doi.org/10.12659/MSM.890073

22. Duggappa DR, Lokesh M, Dixit A, et al. Perfusion index as a predictor of hypotension following spinal anaesthesia in lower segment caesarean section. Indian J Anaesth. 2017;61:649-54. https://doi.org/10.4103/ija.IJA 429 16

23. Chamberlain DP, Chamberlain $\bar{B}$. Changes in the skin temperature of the trunk and their relationship to sympathetic blockade during spinal anesthesia. Anesthesiology. 1986;65:139-43. https://doi.org/10.1097/00000542-198608000-00002

24. Schiller Y. The anatomy and physiology of the sympathetic innervation to the upper limbs. Clin Auton Res. 2003;13:12-5.

https://doi.org/10.1007/s10286-003-1102-6 